\title{
THE ANTHROPOLOGY OF COLONIALISM: Culture, History, and the Emergence of Western Governmentality
}

\section{Peter Pels}

Research Centre Religion and Society, University of Amsterdam, 1012 DK Amsterdam, The Netherlands; e-mail: ppels@pscw.uva.nl

KEY WORDS: ethnography, literary theory, modernity, travel, reflexive anthropology

\begin{abstract}
The study of colonialism erases the boundaries between anthropology and history or literary studies, and between the postcolonial present and the colonial past. From the standpoint of anthropology, it is also reflexive, addressing the colonial use and formation of ethnography and its supporting practices of travel. Since the 1960s, the study of colonialism has increasingly presented a view of colonialism as struggle and negotiation, analyzing how the dichotomous representations that Westerners use for colonial rule are the outcome of much more murky and complex practical interactions. By thus treating Western governmentality as emergent and particular, it is rewriting our histories of the present.
\end{abstract}

The art of government lies in knowing nothing at the proper moment.

Edgar Wallace (1912)

[T]here is too much hypocrisy in East Africa today. The European official and the European settler rule and maintain their prestige mainly by hypocrisy, their inner motives would hardly stand examination; the Indian trader makes his living by downright dishonesty or at best by sheer cunning which is hypocrisy; the African clerk or laborer often disregards fulfilling his part of a contract and even a very educated African will pretend to love the European whereas his heart is nearly bursting with envy and hatred.

Julius Kambarage Nyerere (1952)

$0084-6570 / 97 / 1015-0163 \$ 08.00$ 


\section{INTRODUCTION}

The anthropology of colonialism is neither the exclusive province of anthropologists nor restricted to colonialism. Therefore, this review often penetrates noncolonial territory and colonizes terrain first settled by historians and literary theorists by indulging in the conceit that a subdiscipline such as the anthropology of colonialism can be outlined. This conceit can be legitimized because, from the point of view of anthropology, the study of colonialism presents a unique view and commands a peculiar sense of engagement. For anthropologists, more than for any other type of scholar, colonialism is not a historical object that remains external to the observer. The discipline descends from and is still struggling with techniques of observation and control that emerged from the colonial dialectic of Western governmentality.

Anthropologists mostly think of colonialism in three ways: as the universal, evolutionary progress of modernization; as a particular strategy or experiment in domination and exploitation; and as the unfinished business of struggle and negotiation. All these views, in both positive and negative versions, were common colonial currency. Anthropological views of colonialism commonly stressed a combination of the three. A standard conception of professionalizing anthropology between the wars was that, to avoid colonial struggle-race conflict, indigenous revolt-one should follow a colonial strategy based on anthropological knowledge and planning to achieve the desired evolutionary progress cheaply and without bloodshed (e.g. Malinowski 1929). Around 1970 , anthropologists often told their colleagues to shun collaboration with the powerful in neocolonial planning and strategy. Instead, they were supposed to support "indigenous" peoples in their struggles, to help the latter achieve the modernization that the legacy of colonialism-a perfidious combination of an ideology of modernization and a strategy of exploitation-denied them.

That is, reinventions of anthropology often used images of colonialism as their cutting edge. Only in the past 25 years, however, have such critique and reflexivity become structural, owing to the increasing stress on the third view of colonialism, as a struggle that constantly renegotiates the balance of domination and resistance (Dirks 1992b, Guha 1989, Stoler \& Cooper 1997). Because one cannot simply demarcate a past colonialism from struggles in the present (Dirks 1992b, Thomas 1994), the anthropology of colonialism systematically interrogates contemporary anthropology as well as the colonial circumstances from which it emerged. The anthropology of colonialism is also 
always an anthropology of anthropology, because in many methodological, organizational, and professional aspects the discipline retains the shape it received when it emerged from-if partly in opposition to - early twentiethcentury colonial circumstances. Studying colonialism implies studying anthropology's context, a broader field of ethnographic activity that existed before the boundaries of the discipline emerged and that continues to influence the way they are drawn (Pels \& Salemink 1994).

Anthropology, therefore, needs to be conceptualized in terms of governmentality (Wright 1995), as an academic offshoot of a set of universalist technologies of domination - a Statistik or "state-craft" at least partly based on ethnography - that developed in a dialectic between colonial and European states (Cohn 1987, 1996; Stagl 1995). These forms of identification, registration, and discipline emerged in tension and in tandem with technologies of self-control that fostered notions of cleanliness, domesticity, ethnicity, and civilization (Chakrabarty 1994, Stoler 1995a). Anthropology, in negotiating ethnic, civilized, and savage identities, was at the juncture of these technologies of domination and self-control. It precariously straddled a world of paradox and contradiction in which notions of race were universalistically shunned at the same time that they particularistically helped constitute the nation-state's civilities (Stoler 1995a, Stoler \& Cooper 1997). Both anthropology and colonialism projected seemingly universal and Manichean essentializations of Us and Them, which in practice had to give way to much more complex and particularist negotiations of rule (Pels \& Salemink 1994, Stoler \& Cooper 1997).

\section{ANTHROPOLOGY OF COLONIALISM: GENEALOGIES}

The social-scientific study of colonial society predates the 1960s (Balandier 1963, Mair 1938, Malinowski 1945). After decolonization, however, a set of interests started to converge that can now be regarded as constituting a new departure. Ethnohistory questioned the boundaries between anthropology and history (Cohn 1968, Sturtevant 1966). Those who had been colonized raised doubts about the relevance of anthropology (Deloria 1969, p'Bitek 1970). Neo-Marxist and feminist approaches to peasant societies and their modes of production and the economy of the household fueled an interest in economic change, and consequently in colonialism (Etienne \& Leacock 1980, Hafkin \& Bay 1976, Meillassoux 1964, Wolf 1982; for an overview, see Stoler 1995b). Critical approaches to classical anthropology questioned the nature of the knowledge required for colonial rule and the involvement of anthropologists in its production and paved the way for some of the analytics of knowledge and power that matured later on (Asad 1973, Gough 1968, Hymes 1974). The historical and sociological tum of the Kuhnian philosophy of science helped raise 
doubts about the claim to scientific independence from colonial circumstances that had been made by anthropologists since the early twentieth century.

From the late 1970s onward, this set of interests was further developed by the increasing realization that many features of the discourses developed under and for colonial rule were still operative in present-day anthropology. A critical hermeneutics, sometimes informed by a more epistemologically inclined neo-Marxism, elaborated the continuities between colonial and postcolonial constructions of anthropology's object (Clifford 1982, Fabian 1983, Webster 1982). Analyses of the political role of textual representation, developed by literary theorists (Williams 1977), entered anthropology through the critique of orientalism and other forms of colonial discourse (Barker et al 1985, Bhabha 1994, Clifford \& Marcus 1986, Clifford 1983, Said 1978). By the 1990s, these developments resulted in a paradoxical situation: While the historicizing political economy approaches of the 1970s were criticized because of their lack of a cultural critique (Coronil 1996, Stoler \& Cooper 1997, Taussig 1989), the notions of "culture" and "ethnography" themselves were also criticized for their contribution to colonial and postcolonial essentializations of ethnic entities (Dirks 1992b, Fabian 1983, Pels \& Salemink 1994, Thomas 1994).

Since the early 1990s, anthropologists have moved away from the 1980 s impact of literary theory, feeling that colonial discourse inadequately defines historical anthropology's object of critique (Dirks 1992b, Stoler \& Cooper 1997, Thomas 1994). The analysis of the textual strategies of colonial discourse is increasingly replaced by an effort at contextualization that implies reading ethnographic texts and colonial archives as sites of struggle, and setting them against the practical conditions of the encounter that produced these texts and archives (Dirks 1993a, Stoler 1992, Pels \& Salemink 1994, Stocking 1991, Taussig 1992). The publication of a number of textbooks shows that the anthropology of colonialism has settled down (Cooper \& Stoler 1997, Dirks 1992b, Schwartz 1994, Thomas 1994). But however settled it may be in its own terms, it is often unsettling to other anthropologists, for it tends to destabilize disciplinary identity by questioning anthropology's methods and redefining its contexts.

\section{METHODS AND CONTEXTS; CULTURE AND HISTORY}

Classical anthropologists already suggested that one should study culture contact holistically (Malinowski, in Mair 1938) and study colonizers in the same way as the colonized (Schapera, in Mair 1938). Their emphasis, however, remained on the study of "the changing native," betraying that anthropologists' theories and fieldwork methods were predominantly meant to serve as instruments of governmental planning (Malinowski, in Mair 1938). The culture of 
the colonizer became systematically subject to anthropological scrutiny only after the opportunities for fieldwork among colonizers had disappeared. Now that anthropologists of colonialism find themselves in the realm of history, their notions of method and culture themselves turn out to have had specific colonial uses. To the dismay of some and the delight of others, the concepts of ethnography, fieldwork, participant observation, and even culture and history themselves have to be put in historical context.

Such methodological inquiry has, despite some promising departures, barely begun. Method has, since the late 1960s, silently dropped off the agenda of academic anthropology. Most innovations have come from other disciplines, from history and literary theory in particular. Investigation into the cultural history of method and the political tasks it performed has, despite the early efforts of Walter Ong, only recently gained momentum (Cohn 1996, Fabian 1983, Ludden 1993, Ong 1958, Stagl 1995). Yet it has already made a number of unsettling suggestions. Professional ethnography, for instance, may be better regarded as a specific offshoot of a wider field of colonial intelligence rather than, as most historians of anthropology implicitly assumed, the fulfillment of an intellectual goal to which colonial ethnographies vainly aspired (Pels \& Salemink 1994). Fieldwork is subject to the way local colonial circumstances shaped the field (Schumaker 1997) but also to a history of colonial sciences such as geography, botany, and ethnography, which set up the exotic as a field to be observed (Grove 1995; see below). Observation, participant or not, reflects centuries of so-called visualist bias in the culture of Western science, to which the role of other sensory registers in producing knowledge was subordinated (Fabian 1983). In fact, empiricism in general may be seen to have a political agenda (Ludden 1993), and colonialism is also a set of empirical "investigative modalities" (Cohn 1996).

If ethnography as method is something subject to historical critique, then the concept of culture itself can also be contextualized. As indicated above, the anthropological concept of culture-which enables us to say that colonialism needs to be analyzed as culture-has at least partly emerged as an instrument of colonial control (Dirks 1992b). This argument can, of course, be turned around: Not only can the concept of culture be deconstructed by setting it in the context of a history of colonial control, "history" itself needs to be deconstructed by asking which stories it culturally privileges (Chakrabarty 1992, Prakash 1992). History and culture stand in a supplemental relationship where the one is both necessary for and subversive of the thrust of the other (NB Dirks, unpublished manuscript). To actually realize how culture supplements history and vice versa, we need not only to find out how classifications of culture functioned within strategies of colonial governmentality but how historiography provided governmentality with an ontological underpinning (Cohn 
1996). We require more analyses of alternative histories, not just those "from below" (Fabian 1990, Stoler 1995b) or those analyzing non-European colonialism (Robertson 1995) but those that challenge historiographical "hierarchies of credibility" (Stoler 1992) because they derive from street art, spirit possession, oral tradition, rumor, gossip, and other popular or subaltern forms of knowledge production (Fabian 1996, Kramer 1993, Lambek 1995, Vansina 1985, White 1993).

Much of the search for other histories has been pioneered by historians of Asian, African, or European workers and peasants, and their methodological arsenal has been assiduously plundered by historical anthropologists. Especially the historians of the Subaltern Studies collective (Arnold 1993; Chakrabarty 1992, 1994; Chatterjee 1989, 1993; Guha 1983; Guha et al 1982-1994; Pandey 1990; Prakash 1992) and their Africanist colleagues (Boahen 1987; Cooper 1992, 1996; Feierman 1990, 1993; Kimambo 1991; Ranger 1983, 1989) have provided anthropologists of colonialism with analytics and exemplars: A new phase in the debate between anthropologists and historians has been achieved by the predominantly anthropological argument that the historians' inclination to remain close to the ground of a specific archive needs to be countered by more attention to the archive's cultural construction in past or present (Comaroff \& Comaroff 1992, Dirks 1993a, Stoler 1992).

Historians and anthropologists often agree on the holistic intuition that, above all, one should be sensitive to context. Here, literary theory introduced a peculiar methodological innovation that may last longer than the brief vogue of textual experimentation it bequeathed on anthropology in the 1980s: the need to "[bracket] particular questions of historical accuracy and reliability in order to see the text whole, to gauge the structure of its narrative, and chart the interplay of its linguistic registers and rhetorical modalities" (Hulme 1992). To understand a discourse, one must step back and compare tropes and topoi derived from disparate times and places, that is, decontextualize first to better understand the relevant context of a specific set of utterances or symbols (see also Dirks 1996, Fabian 1995, Thornton 1988, White 1987).

This is indeed a "scandalous" operation (Hulme 1992). It violates the disciplinary boundaries by which many orientalists, historians, or anthropologists felt protected from political challenges. It brings together cultural stereotypes from different contexts-political domination, popular prejudice, academic scholarship-to inquire whether and to what extent they are founded on a similar history of colonial violence. Often such political challenges are fended off by the argument that the likes of Edward Said commit the sin of historical, cultural, or literary de(con)textualization (Boyarin \& Boyarin 1989, Lewis 1993, Otterspeer 1989, Shokeid 1992). Yet the power of discourse analysis is precisely to show the extraordinary redundancies produced by colonial common- 
places across the lines that divide political, economic, religious, and cultural contexts and the disciplines that study them. These redundancies not only explain some of the self-evidence acquired by Western governmentality in its development, their study also gives a new lease of life to cultural analysis [something not always appreciated by anthropologists (see Rosaldo 1994)]. They allow one to trace continuities that go beyond the West's occidental self-images (Carrier 1995): continuities between past colonial and today's professional ethnography (Fabian 1983; Pels \& Salemink 1994; Pratt 1985, 1992; Stewart 1994), or between nineteenth-century reinventions of ethnicity and their present-day deployment (Appiah 1993; Dirks 1992a, 1995; Mudimbe 1988).

In recent years, however, some anthropologists have become impatient with the historical and literary preoccupation with texts, and they have turned away from an exclusively textual notion of culture. Some suspect the culture of literacy that informed Western representations of self and other (Fabian 1983). While studies of the textual strategy of colonial representation have significantly advanced our understanding of its grassroots operation (Mitchell 1991), they insufficiently grasp the contradictions and paradoxes of specific microphysics of colonial struggle, encounter, (knowledge) production, and exchange (Hirschkind 1991; Pels 1996a 1997; Stoler \& Cooper 1997). Analyses of colonialism increasingly stress the nonverbal, tactile dimensions of social practice: the exchange of objects, the arrangement and disposition of bodies, clothes, buildings, and tools in agricultural practices medical and religious performances, regimes of domesticity and kinship, physical discipline, and the construction of landscape (Amold 1993, Cohn 1996, Comaroff 1985, Comaroff \& Comaroff 1997, Eves 1996, Mangan 1986, Pels 1996b, Schumaker 199 , Stoler 1995a). This makes the study of colonialism more anthropologi$\mathrm{cal}$, as older methods of museum studies, physical anthropology and archaeology, or the classical British functionalist injunction to add what people do to what they say about it are reinvented and made relevant to new pursuits.

\section{HOMES, FIELDS, AND THE TRAVELS IN BETWEEN}

If, however, the study of nonverbal practices makes the analysis of colonialism more anthropological, it will also challenge the dichotomous image of twentieth-century anthropology. The dyad of anthropologist and informants and of an academic home juxtaposed to a "field" of research breaks down once one brings the physical work necessary to maintain these dichotomies into the analysis - the work of traveling, making a temporary dwelling, or constructing ethnographic occasions or a "field" in colonial circumstances (Clifford 1992, Pels \& Salemink 1994, Schumaker 199\$ Stocking 1991). The erasure of these practical conditions also deleted colonial and postcolonial governments and 
made them external to the self-conception of anthropology. Just such an erasure of a much more multisided, contradictory, and paradoxical practice by a dichotomous world view characterized colonialism in general (Stoler \& Cooper 1997). The study of colonial discourse may have done much to outline the ambivalent dichotomies between self and other, its tendency to reduce colonial struggle to a form of governmentality that marks out a subject nation in pejorative terms (Bhabha 1994) ignores many of the contradictions, paradoxes, and negotiations that accompany colonial rule (Thomas 1994). For every imaginary opposition of home and field, one must study the hybrid work of travel that links them up.

\section{Conquests and Expeditions}

Given that the view of colonialism as struggle has only recently come to predominate its study, it is not surprising that anthropologists, unlike historians, rarely researched the violent beginnings of colonial occupation. Yet conquests, other colonial wars, and their routines of reconnaissance have a peculiar relationship to colonial mythology and the subsequent structuration of colonial rule. Studies of "first contact" often produced remarkable instances of diverging cultural interpretations of the same events (Connoly \& Anderson 1987, Sahlins 1985, Schieffelin \& Crittenden 1991). Military intelligence employed most colorful and ruthless anthropologists (such as Richard Burton, Christiaan Snouck Hurgronje, or Colonel Creighton in Kipling's Kim). The cultural organization of military prowess and its relative lack of success vis-ávis colonial armies often left a legacy of ethnic distinctiveness under later phases of colonial rule (Forster 1994, West 1994).

It is well known that indigenous religious and magical conceptions played a crucial role in the process and subsequent reinterpretation of successful conquests by Europeans (Connoly \& Anderson 1987; Reid 1994; Sahlins 1985, 1995; Wiener 1995). Such images, however, of the European as god or powerful magician were also recurrent themes of colonial mythology and have, at least in the history of Mexico and Penu, been "unmasked" as second- and thirdgeneration (re)inventions of tradition (Adorno 1994, Gillespie 1989, Lockhart 1994). Do images of cultural difference between conqueror and conquered obscure rather than illuminate the outcome of violent exchanges (the issue of debate between Obeyesekere 1992, Sahlins 1995)? Some cases suggest different conceptualizations of otherness on the part of the conquered (Lockhart 1994). Further accounts suggest that the main difference between Europeans and others was the former's extreme capacity for violence, whether technological (Reid 1994) or cultural and emotional (De Silva 1994). The study of colonial conquest will be crucial in rethinking the relationship of culture and violence. 
Military or other expeditions often forged novel oriental and occidental identities, for the simple reason that the two parties in the encounter were accumulating the experiences that would make them decide whether and how to apply a self/Other dichotomy to a much more multisided set of relationships (Thornton 1995). We have as yet, however, no clear view of the precise sociohistorical conditions within which a bricolage of tactical engagements gave way to colonial strategies based on fairly stable conceptions of otherness. We have very few anthropologically informed studies of the tactical engagements themselves (but see Byrnes 1994, Connoly \& Anderson 1987). Anthropologists of colonialism seem to have taken the military struggle for granted as a material event, forgetting that even a single blow requires cultural preparations. Similarly, barring one excellent exception, we have very few studies of the symbolic process that accompanies colonial violence (Taussig 1992). Other expeditions, which depend on a similar tactical bricolage as military ones, have also yet to receive the attention they deserve, though the study of some of their aspects, such as the circulation of objects (Thomas 1991) or the creation of linguistic knowledge (Fabian 1986) provide tantalizing insights.

\section{Translation, Conversion, and Mission}

The study of Christian missionaries has been a major area of innovation in the anthropology of colonialism. Initial interest, however, was raised by the suspicion of missionaries cultivated by anthropologists since the 1930s. The anthropological Feindbild of missionaries as exemplary colonialist indoctrinators defined the former's activity as an essentially harmless curiosity, and this view informed some of the earliest work on the topic (Beidelman 1981). The study of missions, however, soon complicated that image and contributed some of the more exciting approaches in the anthropology of colonialism.

Much of this work concentrates on how the different worlds of missionary and potential convert are related through language. Urged by the necessity to communicate the Gospel, missionaries did probably more substantial recording of unknown languages than all anthropologiststaken together. Because learning a language implies learning cultural competence, they also had to cope with the relations of power that are constructed by and expressed in hierarchies between languages, their notation and translation, and the conversations that occurred on that basis. All colonial relationships require a language of command, and often its dictionary and grammar were provided by missionaries (Cohn 1996, Fabian 1986). While the indeterminacies of translation gave missionaries much trouble, they also provided potential converts with a certain liberty of meaning (Rafael 1988, 1992). The conversation that developed on this basis was essential for the development of a colonial structure from hith- 
erto separate European and indigenous routines (Comaroff 1985; Comaroff \& Comaroff 1991, 1997).

These studies have shown that it is impossible to separate the missionary movement from broader processes of propagating modernity, anthropology included. Missionaries were central to the emergence and professionalization of ethnology and anthropology in Britain and in the way Britain envisaged its role in the colonies (Dirks 1995, Pels \& Salemink 1994). Missionary education was a crucial factor in the emergence of secularizing strategies in colonial India (Viswanathan 1989), and it often spread the language on which, later, the state's identification of ethnic identities was based (Dirks 1995, Ranger 1989). Religious and secular colonization, therefore, occupy common ground (Fabian 1986, Van der Veer 1995). Yet it is possible to identify differences in attitude between missionaries and colonial administrators. Because of their generally assimilationist attitude, missionaries are less prone to essentialize, because for them, othemess is preferably already in the past. Moreover, they are often engaged with individual converts rather than whole groups, and ethnic and racial essentializations do not occupy the structural position in their texts that one sees in other colonizers' (Pels 1994, Thomas 1994).

Thus, the combination of religious teaching, massive involvement in colonial education, and relative autonomy from the practice of colonial control gave missionaries a special position at the juncture of colonial technologies of domination and self-control. Individually, missionaries often resisted collaboration with colonial authorities, but they supported them by education and conversion. For the colonized, education and conversion became technologies of self-control that enabled subordination at the same time that they structured resistance to Christianity, colonialism, and their trappings. "Conversion to modernity" was the prime locus where technologies of the self and of colonial domination converged (Van der Veer 1995). One should treat the concept of conversion with caution, however. Earlier uses of the term within a theory of modernization (e.g. Horton 1971) carry the idealist connotations of the Protestantism from which it emerged, and this may cause us to ignore the media and alternative cultural interpretations of the transformation (Comaroff \& Comaroff 1991). Such transformations are also accomplished by changes in family and gender patterning; corporeal regimes/ like clothkp, dances, and initiation $\$$; and agricultural and domestic objects and spaces (Comaroff \& Comaroff $\operatorname{sing} / \varphi$ 1997, Eves 1996, Jolly \& MacIntyre 1989, Pels 1996b).

\section{Settlers, Plantations, and Labor}

The study of settler culture was also central to the anthropology of colonialism, partly because plantation economies featured prominently in the marxisant an- 
thropology of the 1970s (see Stoler 1995b), but more importantly because such studies subsequently deepened our understanding of the composition of colonial culture. Caused, on the one hand, by a largely feminist-inspired discovery of colonial domesticity and, on the other, by rethinking the organization of plantation labor violence, this highlighting of the "tensions of empire" much advanced the interpretation of colonialism as a constant struggle rather than as a singular and coherent strategy (Cooper \& Stoler 1989).

By the mid-1980s, feminists had added the study of European women to that of the study of the consequences of colonialism for the colonized (Callaway 1987, Strobel 1991). The study of colonial domesticity showed that to maintain colonial authority along the lines of race, European women had to submit to far stricter rules than was common in the metropole. The colonial state engaged in the racial policing of class boundaries as well (Stoler 1991, 1995a). Similarly, gender distinctions were monitored in the attempt of colonial states to regulate working classes, though such constructions may have been beyond the limits of colonial and in the sphere of self-control (Cooper 1992, White 1990). Colonial authority was bolstered by the often mistaken assumption that European women were less oppressed than indigenous ones, making so-called emancipation a legitimation for intervention (Hafkin \& Bay 1976, Mani 1990). Miscegenation was a major preoccupation of colonial discourse (Wolfe 1994). Occidentalist distinctions between public and private became technologies of self when the colonized introduced them into the public performance of domestic life (Chakrabarty 1994), while in the metropole such technologies of self were developed in reference to the colonies (Davin 1978).

Settler colonialism was, of course, based on expropriation of land, and recent innovative work shows that the cultural consequences of concomitant doctrines of terra nullius have not yet been sufficiently researched (Wolfe $1991,1994)$. Because of their attempts at permanent establishment, settlers left some of the most lasting legacies of colonialism (Thomas 1994), legacies that we often fail to recognize as colonial because they are the product of an internal colonialism in which discussion of the colonized has given way to discussion of minority ethnic groups (Barth 1969, Hechter 1975). Plantations and forced labor were at the root of European colonialism and provided the model for other, non-European practices of exploitation by slavery (Sheriff 1987). Settlers' desire for cheap labor often led them to argue that indigenous workers needed different treatment-by force-than those back in the metropole. This was a crucial feature of the development of late colonial rule (Cooper 1996) and often led to opposition to settlers' concerns by the administrative interest in a colony's strategic stability (Salemink 1991). Ethnology itself emerged from the protest against ethnocidal policies of settler colonies and the consequent need for salvage ethnography (Rainger 1980, Stocking 1971). 
To further study colonial culture, it seems especially important to continue interrogating how the boundaries and relationships between public and private were constructed - where they required the rescheduling of rhythms of domestic and work time (Cooper 1992), the redrawing of standards of public performance [as evidenced by colonial notions of corruption (Pels 1996a)], the rebuilding of towns and cities (Al Sayyad 1992), or the redecorating of the home and the self through consumption (Comaroff \& Comaroff 1997). Public and private are also involved in the forms of classificatory kinship peculiar to colonialism-as yet rarely studied in themselves-such as the Indian colonial administrator's ma-bap or father-mother role, the ubiquitous infantilizing of the colonized, and the peculiar role of so-called universal brotherhood of diverse forms of colonial and anticolonial propaganda and protest. We have only just begun to study the culture of labor regimes and their ascriptions of ethnic essences to coolies, migrant laborers, and former slaves (but see Breman 1989, Thomas 19946 .

\section{ETHNICIZATION AND ITS FRAGMENTS}

In the preceding section, trade was not addressed. Mercantile capitalism prefigured Western technologies of government and their ethnic categorizations in general. William Pietz shows how Dutch merchants were among the first ethnographers to produce non-Christian alterities, articulated on the normal and abnormal exchange of objects. He shows how the concept of fetish, formerly functional within the hybrid relationships of global trade, was made to define the essence of African society. His work should be made paradigmatic for the study of the processes of essentialization that characterize the production of ethnography (Pietz 1985, 1987, 1988). Mercantile ethnicizations also pioneered the imagination of European self and nation-state. Here, too, merchants prefigured modern governmentality by creating the first images of national community (Helgerson 1992) and pioneering the insurance technologies from which probability and statistics would emerge (Hacking 1990). Their metaphors of the ship and the island/helped to shift the notion of economy from family relationships to the more abstract concept of population, a development that is the major marker of the new discourse on government (Foucault 1991; Grove 1995). Although the seventeenth and eighteenth centuries were constitutive of both empires and nations and their tensions and fragments (Cooper \& Stoler 1997, Chatterjee 1993), they have rarely been researched by anthropologists of colonialism.
L Stolem 19gol. 


\section{Statistics and Ethnography}

Statistics and ethnography were the carriers of modern classifications of race, nation, and ethnicity, and fortunately we have an excellent account of the transformations of the art of travel from which they emerged (Stagl 1995). The epistemological shift from the incorporating cosmology of crusade, pilgrimage, and mission to the distancing cosmology of exploration made implicit practices of traveling subject to explicit, written classifications of knowledge that were the methodological predecessors of statistical questionnaires and the anthropologists' Notes and Queries (Fabian 1983). Human beings were simultaneously redefined as analogous to animal and plant species, as ethnic types to be slotted in the pigeonholes of such questionnaires (Thomas 1994). Taxonomy was also at the heart of the new "art of govemment," based, as La Perrière said, on the "right disposition of things, arranged to lead to a convenient end" (cited in Foucault 1991). Europeans seem to have learned the taxonomic management of "things" particularly in governing bounded, isolated units of goods and personnel such as ships (Foucault 1991) and islands (Grove 1995). Such a culture of objects to be managed characterized early trading relationships (Pietz 1985, 1987, 1988) as well as later forms of exploration (Thomas 1991) and became a basic feature of European self-conceptions by laying the groundwork for a museum culture through the curiosity cabinet-where it, again, ties in with the history of anthropology. If, however, the outlines of such a reinterpretation of European colonial culture(s) are there, much more research needs to be done.

What line such research can take can partly be understood from the history of botany, which was both a revolutionary activity in scientific terms and a most practical one in terms of researching the possibilities for colonial revenue from agriculture. From the time of the La Condamine scientific expedition of 1735 onward, Linnean botany had helped to create an international network of scientists (Pratt 1992). It provided, for instance, Dutch, British, or Russian expeditions with German naturalists, creating a circuit for the exchange of knowledge in which much colonial intelligence could be passed on from one empire to another (Slezkine 1994, Thomas 1991). The network of scientific societies and botanical gardens was specifically colonial — rather than metropolitan-and even the knowledge it disseminated was a hybrid of, among other things, Indian and European botanical classifications (Grove 1995). Botanists pioneered the colonial deployment of statistics (Vicziany 1986). Anthropologists of colonialism, however, still need to catch up with the recent advances made in the (colonial) history of science and research its significance for the development of colonial rule. Since most colonial naturalists were medical men, this is obviously also a history of colonial conceptions of the body and 
disease, the more important because before the rise of the clinic in the nineteenth century the confrontation of European and other medical systems was one between more or less equally effective practices of curing.

The study of colonial statistics can also yield more results. It is clear that governmental notions of population and economy, and the "numbering" they necessarily imply, were pioneered in the colonies (Appadurai 1993, Hacking 1990). While some of the best work in the anthropology of colonialism has shown the importance of census and statistics in establishing colonialism and modem governmentality (Anderson 1991, Cohn 1987), much research is needed on how they emerged from colonial insurance and political arithmetic. Moreover, while we assume that ethnography and statistics, after having been coined together in the late eighteenth century (Stagl 1995), parted company at the beginning of the twentieth century (Asad 1994), little research has been done on how this happened, on the role colonial experience played in this development (see Dirks 1996), and on the possibility of comparing nineteenthcentury ethnography and statistics with twentieth-century anthropological surveys such as the Human Relations Area Files (Cohn 1996).

\section{Inventions of Tradition and Modernity}

Seventeenth- and eighteenth-century exemplars developed technologies of domination that have recently been studied: the regime of representation (Mitchell 1991, Rabinow 1989); the rise of environmentalism, crucial to utilitarianism and functionalism (Grove 1995) as well as to the emergence of sanitation (Arnold 1993, Thomas 1994); colonial map-making (Noyes 1992); the agricultural and social improvement of villages necessary for colonial revenue (Breman 1988, Dewey 1972, Guha 1989); or the development of colonial policing (Amold 1993, Dirks 1996). It is still unusual for researchers to fully escape the dichotomy of colonial state and oppressed and/or resistant others, and realize how much colonial empires were fragmented by other tensions (Stoler \& Cooper 1997). Empires were maintained by ethnic soldiers that fought the colonized at the same time that they colonized themselves (Fox 1985), or by white women subordinating their domestic staff while they were acting out their own subordination (Stoler \& Cooper 1997). The present emphasis on governmentality as a pervasive form of power should not obscure that one's hegemony was often the other's coercion. Surely, governmentality should be understood as a power dispersed through the social body. It cannot be regarded as a singular colonial strategy, and we should study the struggles going on among groups of colonizers and the colonized and between them, not only over the control of governmental technologies but also over their appropriateness, application, and desirability. 
The most influential argument in this respect is that of the invention of tradition under colonial circumstances: the use of an image of tribal or traditional government within strategies of indirect rule (Ranger 1983). Such an image of other government and its tension with ethnocentric definitions of modern government were crucial to any form of colonial rule (Mamdani 1996). The contradiction between other and modern government was founded on a similar infrastructure of representation (Mitchell 1991). However, the notion of invented tradition privileged European agency and regarded the tradition too much as an ideology imposed on, rather than coauthored with or resisted by, sections of colonized groups (Dirks 1993b, Pels 1996a, Thomas 1992).

Moreover, we cannot restrict ourselves to inventions of tradition; modernity itself needs to be imagined and constructed as well. It is here that analytic perspectives on alternative imaginings of history, of the public/private or work/home dichotomies, or of Christianity (Chakrabarty 1994, Cooper 1992, Mbembe 1992, Pels 1996b, White 1993) may prove to be important to future developments in the anthropology of colonialism. They shall, for instance, raise the question of the extent to which governmentality is synonymous with Western culture as such, whether it can be regarded as a whole, or whether it is a set of technologies that lend themselves to selective adoption into alternative governmentalities. Similarly, they should address to what extent colonialism has triggered subaltern processes of global communication such as black culture, rumor, art, or possession (Appiah 1993, Kramer 1993, Pels 1992).

\section{CONCLUSION: HISTORIES OF THE PRESENT}

The mottoes at the beginning of this review argue that colonialism was a contradictory project. Like modern anthropology, it tends to bracket out part of the self to know and/or rule the other, or vice versa. If Mr. Commissioner Sanders should know nothing of the cruel measures his African "indirect ruler" needed to keep Sanders's peace, it is clear from Nyerere's statement that this hypocrisy of domination penetrated the self-control of all participants in the colonial process. Anthropology, too, has often denied that it knew anything of colonialism, to the point of making colonialism into the definition of what anthropology is not (e.g. Beidelman 1981). If we are now in a position to overcome that denial by doing the anthropology of colonialism as an anthropology of anthropology, this indicates that, after Humboldt, we are capable or in need of separating ourselves from a phase in which anthropology and colonial rule were part of the same social formation: the world of modernity, development, and the welfare state.

This makes the anthropology of colonialism a historiography of the present. After colonialism comes the postmodern; the latter cannot be understood ex- 
cept as postcolonial (Appiah 1993, Thomas 1994). Postcolonial societies are mainly based on development regimes constructed under colonial rule (Ludden 1992), regimes that inherited the colonial inclination to excise politics from economic and administrative practice (Ferguson 1990, Fields 1985, Pels 1996a). Governmentality was, like social science, a political technology meant to prevent coercion and politics (Malinowski 1929; Rabinow 1989). The bifurcation, however, of colonial polities into traditional and modern often functioned to facilitate coercive practices such as forced labor (Cooper 1996) or tribalism, communalism, and apartheid (Mamdani 1996, Pandey 1990). We are not only in need of more studies of the simultaneous emergence of modernity and colonialism in the seventeenth and eighteenth centuries, but of more ethnographies of decolonization, focusing on the continuity between present and past practices of development, welfare, and good governance, and the way they were constituted by anthropology, economics, and political science. If we are ever going to be capable of disengaging anthropology from colonialism, we first need to reflexively blur the boundaries between colonialism and our present anthropology.

\section{ACKNOWLEDGMENTS}

I thank Peter van der Veer and the Editorial Committee of the Annual Review of Anthropology for encouraging me to write this review. Much of its inspiration has been derived from several years of conversation on the topic with Oscar Salemink, and from a sojourn among staff and students of the University of Michigan's anthrohistory program in 1995, made possible by UM's International Institute and the Dutch Royal Academy of Sciences. I am grateful to Nicholas Dirks, Johannes Fabian, Lynette Schumaker, Nicholas Thomas, and Peter van der Veer for their comments on an earlier draft of the review.

Visit the Annual Reviews home page at http://www.annurev.org.

\section{Literature Cited}

Adorno R. 1994. The indigenous ethnographer: the "indio ladino" as historian and cultural mediation. See Schwartz 1994, pp. 378-402

Al Sayyad N, ed. 1992. Forms of Dominance. On the Architecture and Urbanism of the Colonial Enterprise. Aldershot: Avebury

Anderson B. 1991. Imagined Communities. Reflections on the Origin and Spread of Nationalism. London: Verso. 2nd ed.
Appadurai A. 1993. Number in the Colonial Imagination. See Breckenridge \& Van der Veer 1993, pp. 314-39

Appiah KA. 1993. In My Father's House. Africa in the Philosophy of Culture. London: Methuen

Arnold D. 1993. Colonizing the Body. State Medicine and Epidemic Disease in Nineseenth-Century India. Berkeley: Univ. Calif. Press 
Asad T, ed. 1973. Anthropology and the Colonial Encounter. London: Ithaca Press

Asad T. 1994. Ethnography and statistical representation Soc Res 6.55-88

Balandier G, ed. 1963. (1955). Sociologie AC. tuelle de l'Afrique Noire. Paris: Press. Univ. France

Barker F, Hulme P, Iversen M, Loxley D, eds. 1985. Europe and Its Others. Colchester: Univ. Essex

Barth F, ed. 1969. Ethnic Groups and Boundaries. Bergen/London: Univ. Forlaget/Allen \& Unwin

Beidelman TO. 1981. Colonial Evangelism. Bloomington: Indiana Univ. Press

Bhabha HK. 1994. The Location of Culture. London/New York: Routledge

Boahen AA. 1987. African Perspectives on Colonialism. Baltimore: Johns Hopkins Univ. Press

Boyarin D, Boyarin J. 1989. Toward a dialogue with Edward Said. Crit. Inq. 15: $626-33$

Breckenridge CA, Van der Veer P, eds. 1993. Orientalism and the Postcolonial Predicament. Perspectives on South Asia. Philadelphia: Univ. Pa. Press

Breman JC. 1988. The Shattered Image: Construcion and Deconstruction of the Village in Colonial Asia. Dordrecht: Foris/CASA

Breman JC. 1989. Taming the Coolie Beast. Plantation Society and the Colonial Order in Southeast Asia. Delhi: Oxford Univ. Press

Burchell G, Gordon C, Miller P, eds. 1991 The Foucault Effect. Studies in Governmentality. Chicago: Univ. Chicago Press

Byrnes G. 1994. 'The imperfect authority of the eye ": Shorland's southern journey and the calligraphy of colonialism. See Pels \& Salemink 1994, pp. 207-35

Callaway H. 1987. Gender, Culture and Empire. European Women in Colonial Nigeria. Oxford: Macmillan

Carrier JG, ed. 1995. Occidentalism. Images of the West. Oxford: Clarendon

Chakrabarty D. 1992. Postcoloniality and the artifice of history: Who speaks for 'Indian' pasts? Representations 37:1-26

Chakrabarty D. 1994. The difference-deferra of a colonial modernity: public debates on domesticity in British India. Subaltern Stud. 8:50-88

Chatterjee P. 1989. Nationalist Thought and the Colonial World: A Derivative Discourse? London: Zed Books

Chatterjee P. 1993. The Nation and Its Fragments. Colonial and Postcolonial Histories. Princeton, NJ: Princeton Univ. Press

Clifford J. 1982. Person and Myth: Maurice
Leenhardt in the Melanesian World. Berkeley: Univ. Calif. Press

Clifford J. 1983. On ethnographic authority. Representations 2:118-46

Clifford J. 1992. Traveling Cultures. Cult. Stud. New York/London: Routledge

Clifford J, Marcus G, eds. 1986. Writing Culture. The Poetics and Politics of Ethnography. Berkeley: Univ. Calif. Press

Cohn BS. 1968. Ethnohistory. Int. Enc. Soc. Sci. 5:440-48. New York: MacMillan, Free Press

Cohn BS. 1987. An Anthropologist Among the Historians and Other Essays. Delhi: Oxford Univ. Press

Cohn BS. 1996. Colonialism and lts Forms of Knowledge. The British in India. Princeton, NJ: Princeton Univ. Press

Comaroff J. 1985. Body of Power, Spirit of Resistance. The Culture and History of a South African People. Chicago: Univ. Chicago Press

Comaroff J, Comaroff J. 1991. Of Revelation and Revolution, Vol. 1. Chicago: Univ. Chicago Press

Comaroff J, Comaroff J. 1992. Ethnography and the Historical Imagination. Chicago: Univ, Chicago Press

Comaroff J, Comaroff J. 1997. Of Revelation and Revolution, Vol. 2. Chicago: Univ. Chicago Press

Connoly B, Anderson R. 1987. First Contact. New Guinea's Highlanders Encounter the Outside World Harmondsworth: Penguin

Cooper F. 1992. Colonizing time: work rhythms and labour conflict in colonial Mombasa. See Dirks 1992 b, pp. 209-45

Cooper F. 1996. Development and African Society. The Labor Question in French and British Africa. Cambridge: Cambridge Univ. Press

Cooper F, Stoler AL, eds. 1997. Tensions of Empire. Colonial Cultures in a Bourgeois World. Berkeley: Univ. Calif. Press

Cooper F, Stoler AL, eds. 1997. Tensions of Empire. Colonial Cultures in a Bourgeois World. Berkeley: Univ. Califomia Press

Coronil F. 1996. Beyond Occidentalism: toward nonimperial geohistorical categories. Cult. Anthropol. 11(1):1-37

Davin A. 1978. Imperialism and motherhood. Hist. Workshop 5:9-57

Deloria V 1969. Custer Died For Your Sins. An Indian Manifesto. New York: Avon

De Silva CR. 1994. Beyond the Cape: the Portuguese encounter with the peoples of South Asia. See Schwartz 1994, pp. 295-322

Dewey C. 1972. Images of the village commu- 
nity: a study in Anglo-Indian ideology. Mod. Asian Siud 6:291-328

Dirks NB. 1992a. Castes of mind. Representations 37:56-78

Dirks NB, ed. 1992b. Colonialism and Culture. Ann Arbor: Uniy. Mich. Press

Dirks NB. 1993a. Colonial histories and native informants: biography of an archive. See Breckenridge \& Van der Veer 1993, pp. 279-313

Dirks NB. 1993b. The Hollow Crown. Ethnohistory of an Indian Kingdom. Ann Arbor: Univ. Michigan Press. 2nd ed.

Dirks NB. 1995. The conversion of caste: 10cation, translation and appropriation. See Van der Veer 1995, pp. 115-36

Dirks NB. 1996. Reading Culture. Anthropology and the Textualization of India. In Culture/Contexture. Explorations in Anthropology and Literary Studies, ed. EV Daniel, JM Peck. Berkeley: Univ. Calif. Press

Etienne M, Leacock E, eds. 1980. Women and Colonization. Anthropological Perspectives. New York: Praeger

Eves R. 1996. Colonialism, corporeality and character: Methodist missions and the refashioning of bodies in the Pacific. Hist. Anthropol. 10:85-138

Fabian J. 1983. Time and the Other: How Anthropology Makes Its Object. New York: Columbia Univ. Press

Fabian J. 1986. Language and Colonial Power: The Appropriation of Swahili in the Former Belgian Congo, 1880-1938. Cambridge: Cambridge Univ. Press

Fabian J. 1990. History from Below: The "Vocabulary of Elisabethville" by Andre Yav. Texts, Translation, and Interpretive Essay. Amsterdam/Philadelphia: Benjamins

Fabian J. 1995. Ethnographic misunderstanding and the perils of context. Am. Anthropol. 97:41-50

Fabian J. 1996. Remembering the Present. Painting and Popular History in Zaire. Berkeley: Univ. Calif. Press

Feierman S. 1990. Peasant Intellectuals. Anthropology and History in Tanzania. Madison: Univ. Wis. Press

Feierman S. 1993. African histories and the dissolution of world history. In Africa and the Disciplines. The Contribution of Research in Africa to the Social Sciences and Humanities, ed. R Bates, $V$ Mudimbe, J O'Barr, pp. 167-212. Chicago: Univ. Chicago Press

Ferguson J. 1990. The Anti-Politics Machine: "Development", Depoliticization and Bureaucratic Power in Lesotho. Cambridge: Cambridge Univ. Press
Fields KE. 1985. Revival and Rebellion in Colonial Central Africa. Princeton, $\mathrm{NJ}$ : Princeton Univ. Press

Forster P. 1994. Politics, ethnography and the "invention of tradition": the case of T. Cullen Young of Livingstonia Mission, Malawi. See Pels \& Salemink 1994, pp. 299-320

Foucault M. 1991. Governmentality. See Burchell et al 1991, pp. 87-104

Fox RB. 1985. Lions of the Punjab. Culture in the Making. Berkeley: Univ. Calif. Press

Gillespie SD. 1989. The Aztec Kings. The Construction of Rulership in Mexica History. Tucson: Univ. Arizona Press

Gough K. 1968. Anthropology: child of imperialism. Mon. Rev. 19(11):12-27

Grove R. 1995. Green Imperialism. Colonial Expansion. Tropical Island Edens and the Origin of Environmentalism, $1600-1860$. Cambridge: Cambridge Univ. Press

Guha R. 1983. Elementary Aspects of Peasant Insurgency in Colonial India. Delhi: Oxford Univ. Press

Guha R. 1989. Dominance without hegemony and its historiography. In Subaltern Siudies, ed. R Guha, 6:210-309. Delhi: Oxford Univ. Press

Guha R, Amold D, Chatterjee P, Hardiman D, Pandey G, eds. 1982-1994. Subaltern Studies. Delhi: Oxford Univ. Press

Hacking I. 1990. The Taming of Chance. Cambridge: Cambridge Univ. Press.

Hafkin NJ Bay EG, eds. 1976. Women in Af. rica. Studies in Social and Economic Change. Stanford: Stanford Univ. Press

Hechter M. 1975. Internal Colonialism. The Celtic Fringe in British Nationa! Development, 1536-1966. Berkeley: Univ. Calif. Press

Helgerson R. 1992. Camoes, Hakluyt, and the Voyages of Two Nations. See Dirks 1992b, pp. 27-63

Hirschkind C. 1991. "Egypt at the exhibition": reflections on the optics of colonialism. Crit Anthropol 11:279-98

Horton R. 1971. African conversion. Africa $41: 85-108$

Hulme P 1992 Colonial Encounters. Europe and the Native Caribbean 1492-1797. London/New York: Routledge

Hymes D, ed. 1974. Reinventing Anthropology. New York: Vintage

Jolly M, MacIntyre M, eds. 1989. Family and Gender in the Pacific. Cambridge: Cambridge Univ. Press

Kimambo I. 1991. Penetration and Protest in Tanzania London/Dar es Salaam/Nairobi/ Athens: Currey/Tanzania Publ. House/ Heincmann/Ohio Univ. Press 
Kramer F. 1993. The Red Fez. Art and Spirit Possession in Africa. London: Verso

Lambek M. 1995. The poiesis of Sakalava history. Presented at 11th Satterthwaite

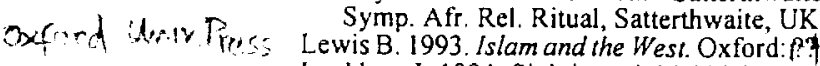

Lockhart J. 1994. Sightings: initial Nahua reactions to Spanish culture. See Schwarz 1994, pp. $218-48$

Ludden D. 1992. India's development regime See Dirks 1992b, pp. 247-87

Ludden D. 1993. Orientalist empiricism. See Breckenridge \& Van der Veer 1993, pp. 250-78

Mair L, ed. 1938. Methods in the Study of Culture Contact. Oxford: Oxford Univ. Press

Malinowski B. 1929. Practical anthropology. Africa 2:22-38

Malinowski B. 1945. The Dynamics of Culture Change. New Haven: Yale Univ. Press

Mamdani M. 1996. Citizen and Subject. Contemporary Africa and the Legacy of Late Colonialism. Princeton, NJ: Princeton Univ. Press

Mangan JA. 1986. The Games Ethic and Imperialism. New York: Viking Penguin

Mani L. 1990. Contentious traditions: the debate on sati in colonial India. In Recasting Women: Essays in Indian Colonial History, ed. K Sangari, S Vaid. New Brunswick: Rutgers Univ. Press

Mbembe A. 1992. Provisional notes on the postcolony. Africa 62:3-37

Meillassoux C. 1964. Anthropologie économique des Gouro de Côre d'lvoire. Paris: Mouton

Mitchell T. 1991. Colonizing Egypt. Berkeley: Univ. Calif. Press. 2nd ed.

Mudimbe V. 1988. The Invention of Africa. Bloomington: Indiana Univ. Press

Noyes J. 1992. Colonial Space. Spatiality in the discourse of German South West Africa, 1884-1914. Chur, Reading: Harwood

Nyerere JK. 1966. (1952). Freedom and Unity. Dar es Salaam: Oxford Univ. Press

Obeyesekere G. 1992. The Apotheosis of Cap tain Cook: European Mythmaking in the Pacific. Princeton, NJ: Princeton Univ. Press

Ong W. 1958. Ramus: Method and the Decay of Dialogue. Cambridge: Harvard Univ. Press

Otterspeer W. 1989. The ethical imperative. In Leiden Oriental Connections, 1850-1940, ed. W Otterspeer. Leiden !

$f: b i$

Pandey G. 1990. The Consiruction of Communalism in Colonial North India. Delhi: Oxford Univ. Press

p'Bitek O. 1970. African Religions in Western Scholarship. Nairobi: Kenya Lit. Bur.
Pels P. 1992. Mumiani: the white vampire. A neo-diffusionist analysis of rumour. Etnofoor 5(1-2):165-87

Pels P. 1994. The construction of ethnographic occasions in late colonial Uluguru. See Pels \& Salemink 1994, pp. 32 $\mid-5 !$

Pels P. 1996a. The pidginization of Luguru politics. Administrative ethnography and the paradoxes of indirect rule. Am. Ethnol. 23(4):738-61

Pels P. 1996b. Kizungu rhythms. Luguru Christianity as Ngoma. J. Rel/1. Afr. 26(2): 163-201

Pels P, Salemink O, eds. 1994. Colonial Ethnographies. Hist. Anthropol. 8:1-352

Pietz W. 1985. The problem of the fetish. I. Res $9: 5-17$

Pietz W. 1987. The problem of the fetish. Il. The origin of the fetish. Res 13:23-45

Pietz W. 1988. The problem of the fetish. III. Bosman's Guinea and the enlightenment theory of fetishism. Res 16:105-123

Prakash G. 1992. Writing post-Orientalist histories of the Third World: Indian historiography is good to think. See Dirks 1992b, pp. 353-88

Pratt ML. 1985. Scratches on the face of the country, or: What Mr. Barrow saw in the land of the bushmen. Crit. Ing. 12:119-43

Pratt ML. 1992. Imperial Eyes. Travel Writing and Transculturation. London/New York: Routledge

Rabinow P. 1989. French Modern. Norms and Forms of the Social Environment. Cambridge, MA: MIT Press

Rafael VL. 1988. Contracting Colonialism. Translation and Christian Conversion in Tagalog Society under Early Spanish Rule. Ithaca, NY: Cornell Univ. Press

Rafael VL. 1992. Confession, conversion and reciprocity in early Tagalog colonial society. See Dirks 1992b, pp. 65-88

Rainger R. 1980. Philanthropy and science in the 1830s: the British and Foreign Aborigines' protection society. Man (NS) is: 702-17

Ranger TO. 1983. The invention of tradition in colonial Africa. In The Invention of Tradition, ed. E Hobsbawm, TO Ranger. Cambridge: Cambridge Univ. Press

Ranger TO. 1989. Missionaries, migrants and the Manyika: the invention of ethnicity in Zimbabwe. In The Creation of Tribalism in Southern Africa, ed. L Vail, pp. 118-50. London/Berkcley: Currey/Univ. Calif. Press

Reid A. 1994. Early Southeast Asian categories of Europeans. See Schwartz 1994, pp. 268-94

Robertson J. 1995. Mon Japon: the revue thea- 


\section{PELS}

ter as a technology of Japanese imperialism. Am. Ethnol. 22:970-96

Rosaldo R. 1994. Whose cultural studies? Am. Anthropol. 96:524-29

Sahlins M. 1985. Islands of History. Chicago/ London: Univ. Chicago Press

Sahlins M. 1995. How "natives" think. About Captain Cook, for example. Chicago: Univ. Chicago Press

Said E. 1978. Orientalism. Harmondsworth: Penguin

Salemink O. 1991. Mois and Maquis. The invention and appropriation of Vietnam's Montagnards from Sabatier to the ClA. See Stocking 1991, pp. 243-84

Schieffelin EL Crittenden R eds 1991 Like People You See in a Dream. First Contact in Six Papuan Societies. Stanford: Stanford Univ. Press

$0 /$ Schumaker L. 1997 A tent with a view: colonial officers, anthropologists, and the making of the field in Northern Rhodesia.

$11: 237-58$ Osiris. In-presel

Schwartz SB, ed. 1994. Implicit Understandings. Observing, Reporting, and Reflecting on the Encounters Benveen Europeans and Other Peoples in the Early Modern Era. Cambridge: Cambridge Univ. Press

Sheriff A. 1987. Slaves, Spices and Ivory in Zanzibar. Integration of an East African Commercial Enterprise into the World Economy, 1770-1873. London/Nairobi/ Dar es Salaam/Athens: Currey/Heinemann/Tanzania Publ. House/Ohio Univ. Press

Shokeid M. 1992. Commitment and contextual study in anthropology. Cult. Anthropol 7:464-77

Slezkine Y. 1994. Naturalists versus nations: eighteenth-century Russian scholars confront ethnic diversity. Representations 47 : $170-95$

Stagl J. 1995. A History of Curiosity. The The ory of Travel 1550-1800. Chur: Harwood Acad.

Stewart S. 1994. Crimes of Writing. Durham: Duke Univ Press

Stocking GW. 1971. What's in a name? The origins of the Royal Anthropological Inst. Man (NS) 6:369-90

Stocking GW ed 1991. Colonial Situations. Essays on the Contextualization of Ethnographic Knowledge. History of Anthropology Vol. 7. Madison: Univ. Wis. Press

Stoler AL. 1991. Carnal knowledge and imperial power. gender, race, and morality in colonial Asia In Gender at the Crossroads of Knowledge: Feminist Anthropology in the Postmodern Era, ed. M Di Leonardo, pp. 51-101. Berkeley: Univ. Calif. Press
Stoler AL 1992. 'In cold blood' hierarchies of credibility and the politics of colonial narratives. Representations 37:151-89

Stoler AL, 1995a. Race and the Education of Desire. Foucault's History of Sexuality and the Colonial Order of Things. Durham NC: Duke Univ. Press

Stoler AL. 1995b. [P]refacing capitalism and confrontation in 1995. In Capitalism and Confrontation in Sumatra's Plantation Belt, 1870-1979, ed. AL Stoler, pp. vii-xxxiv. Ann Arbor: Univ. Mich. Press. 2nd ed.

Stoler AL, Cooper F. 1997. Between metropole and colony. Rethinking a research agenda. In Cooper \& Stoler 1997, pp. $1-56$

Strobel M. 1991. European Women and the Second British Empire. Bloomington: Indiana Univ. Press

Sturtevant WB. 1966. Anthropology, history and ethnohistory. Ethnohistory 13:1-5

Taussig M. 1989. History as commodity in some recent American (anthropological) literature. Crit. Anthropol. 9:70-23

Taussig M. 1992. Culture of terror-space of death: Roger Casement's Putumayo report and the explanation of torture. See Dirks 1992b, pp. 135-73

Thomas N. 1991. Entangled Objects. Exchange, Material Culture and Colonialism in the Pacific. Cambridge, MA: Harvard Univ. Press

Thomas $N$. 1992. The inversion of tradition. Am. Ethnol 19:213-32

Thomas N. 1994. Colonialism's Culture. Anthropology, Travel and Government. London: Polity Press

Thornton RJ. 1988. The rhetoric of ethnographic holism. Cult. Anthropol. 3: 285-303

Thomton RJ 1995. The colonial the imperial and the creation of the 'European' in Southern Africa. See Carrier 1995, pp. 192-217

Vansina J. 1985. Oral Tradition as History. London: Currey

Van der Veer P, ed. 1995. Conversion to Modernities: The Globalization of Christianity. New York/London: Routledge

Vaughan M. 1991. Curing Their Ills: Colonial Power and African Illness. Cambridge/ Stanford: Polity Press \& Stanford Univ. Press

Vaughan M. 1994. Colonial discourse theory and African history, or has postmodernism passed us by? Soc. Dyn. 20(2):1-23

Vicziany M. 1986. Imperialism, botany and statistics in early nineteenth-century India: the surveys of Francis Buchanan 